\title{
Prevalence of Hepatitis B Virus infection and associated factors among female sex workers using respondent-driven sampling in Hawassa City, Southern Ethiopia
}

Deresse Daka ${ }^{1 *}$, Getahun Hailemeskel $^{2}$ and Demissie Assegu Fenta ${ }^{1}$

\begin{abstract}
Background: Female sex workers (FSWs) are a marginalized group notoriously having limited healthcare access and poor-quality care. Inevitably, they are vulnerable to sexually transmitted infections including hepatitis B virus. However; Hepatitis B virus infection is one of the most serious infections and major public health problem considered to be at soaring risk for transmission and acquisition of the infection. Hence, this study was aimed to assess the prevalence and associated factors of HBV infections among FSWs in southern Ethiopia.
\end{abstract}

Methods: A cross-sectional study was conducted from November to February 2019 at Hawassa city in ISHDO confidential clinic among 383 FSWs. Respondent-driven consecutive sampling was used to select study participants using a standardized questionnaire. Blood sample was collected and viral surface antigen was detected using ELISA from separated serum. Data were entered to SPSS version 21.0. Descriptive and logistic regression analyses were used.

Result: The overall prevalence of FSWs who were tested for HBV using ELISA was 35(9.2\%) (95\% Cl: 6.3-12.1). Among 381 FSWs 249(65.4\%) were stayed for 2-5years in sexual work and 240(63\%) of them were used condom consistently during sexual practice. In multivariate logistic regression analysis, FSWs who didn't use condom were six and two times more risk full to acquire HBV than those who used condom commonly ( $\mathrm{AOR}=6.38, \mathrm{Cl} 2.04-18.51$ ) and condom breakage ( $A O R=2.10, C l 1.95-4.65)$, during sexual practice respectively. Similarly, use of stimulants ( $A O R=3.25$, Cl 1.59-18.63), previous history of STI ( $A O R=2.15, \mathrm{Cl} 1.02-6.93)$, genital ulcer ( $A O R=4.64, \mathrm{Cl} 1.31-11.35)$, number of sexual partners ( $A O R=3.25, \mathrm{Cl} 1.59-7.47)$, sex during menses ( $A O R=5.85, \mathrm{Cl}(1.29-21.44)$, sexual assault $(A O R=2.93$, $\mathrm{Cl}$ 1.23-9.01), sharp material sharing, ( $\mathrm{AOR}=4.98, \mathrm{Cl} 1.34-10.95)$ and history of abortion, $(\mathrm{AOR}=2.46, \mathrm{Cl} 1.18,12.19)$, were statistically associated with HBV infection. Factors such as age, residence, and alcohol consumption were not associated with HBV infection.

Conclusion: The prevalence of HBV infection in this study was relatively high compared to the general population. Factors like sociodemographic, behavioral, and previous history-related information were associated with HBV infection shows the need for ongoing screening of high-risk population to inform planning for vaccination and preventive measures.

Keywords: Hepatitis B virus, Female sex workers, Hawassa, Ethiopia

\footnotetext{
*Correspondence: demissieasegu@yahoo.com

${ }^{1}$ School of Medical Laboratory Science, College of Medicine and Health

Science, Hawassa University, Hawassa, Ethiopia

Full list of author information is available at the end of the article
}

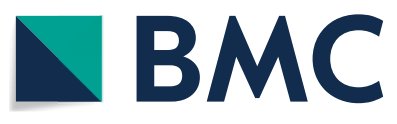

(c) The Author(s) 2022. Open Access This article is licensed under a Creative Commons Attribution 4.0 International License, which permits use, sharing, adaptation, distribution and reproduction in any medium or format, as long as you give appropriate credit to the original author(s) and the source, provide a link to the Creative Commons licence, and indicate if changes were made. The images or other third party material in this article are included in the article's Creative Commons licence, unless indicated otherwise in a credit line to the material. If material is not included in the article's Creative Commons licence and your intended use is not permitted by statutory regulation or exceeds the permitted use, you will need to obtain permission directly from the copyright holder. To view a copy of this licence, visit http://creativecommons.org/licenses/by/4.0/. The Creative Commons Public Domain Dedication waiver (http://creativeco mmons.org/publicdomain/zero/1.0/) applies to the data made available in this article, unless otherwise stated in a credit line to the data. 


\section{Background}

Hepatitis B virus (HBV) is a DNA virus belonging to the Hepadnaviridae family $[1,2]$. Despite the availability of a safe and effective vaccine against hepatitis $B$ infection for over two decades now, the overall burden of the disease remains enormous with over two billion people infected worldwide and approximately one million deaths occur annually from HBV-related illness [1,3]. According to the WHO report over 240 and 150 million populations were infected with chronic liver disease due to $\mathrm{HBV}$ and $\mathrm{HCV}$ respectively $[1]$.

Hepatitis B virus is endemic in sub-Saharan Africa, and despite the introduction of universal hepatitis $B$ vaccination and effective antiviral therapy, the estimated overall seroprevalence of hepatitis B surface antigen remains high at $6 \cdot 1 \%$ [4].

Hepatitis B virus prevalence is highest in an adult population of the Western Pacific Region and Africa, where 6.2 and $6.1 \%$ respectively $[4,5]$. The prevalence of HBV infection among the general population of the Eastern Mediterranean Region, South-East Asia, Europe, and Americas, was 3.3, 2.0, 1.6\%, and 0.7 respectively [5]. It is mentioned that Africa is one of the continents with the highest prevalence of HBV and Ethiopia being a member of these continents and shares the burden [1].

Hepatitis B virus is usually transmitted through exposure to infected blood and various body fluids (saliva, menstrual, vaginal, and seminal fluids) and recycle of needles and syringes either in healthcare settings or along with persons who inject drugs. Furthermore; the infection can arise during medical, surgical, and dental procedures, through tattooing, or through the utilization of razors and related objects that are contaminated with infected blood [5].

The prevalence of HBV among female sex workers in different studies conducted in African countries revealed that $4.2 \%$ in the Republic of Congo [6], 17.1\% in Nigeria [7], 18.2\% Burkina Faso [8], 4\% in South Africa [9], and $2.5 \%$ in Ruanda [10]. From limited studies in Ethiopia, the highest prevalence was reported from Gondar 28.9\% [11], Mekelle 6\% [12], and Dessie 13.1\% [13]. In other developed countries such as Brazil [14], China [15], Thailand [16], and India [17] the prevalence of HBV among Female sex workers was $23.6,10.7,11.4$, and $3.6 \%$ respectively.

Different factors such as workplace associated factors, inconsistent condom use, substance, and drug use [12] economic factors, marital interruption, low educational status, and unsafe alcohol use, and co-infection with other sexually transmitted infections were factors associated with HBV infection [9].

Sex work remains an important contributor to HBV and HIV transmission within early, advanced, and regressing epidemics in sub-Saharan Africa, and its social and behavioral factors play an important role in the transmission of these diseases [5]. Female sex workers (FSW) are more prone to HBV and other sexually transmitted infections (STIs) as well as transmitting them to the public through their clients as they are often in a poor position to negotiate safe sex because of social, economic, cultural, and legal factors [18].

In sub-Saharan Africa, FSW constitutes one of the high-risk groups for HBV and STI acquisition and transmission. This is possibly sex workers have numerous sexual partners and they engage in unprotected sex and other forms of sex that cause contact with body fluids of a partner who may be infected with HBV [19].

According to 2019, Ethiopian demographic and health survey (EDHS) data of Ethiopia represents a stable, low-level, generalized epidemic with marked regional variations driven by most at-risk populations (MARPs). However, urban areas and females are more affected than rural areas and males [20]. Small towns are also becoming hot spots and can potentially bridge further the spread of HIV and HBV epidemic to rural settings by such population groups. Across the country, FSW carries a disproportionate burden of HIV and HBV [20]. A study conducted in Gondar and Mekele among FSW indicated the prevalence of $\mathrm{HBV}$ was 28.9 and $6 \%$, respectively [11, 12]. These findings were greater than the findings from the Ethiopian general population 9\% [21], from adult population in southwest Ethiopia 9\% [22], and from a health professional in Gondar, 4.52\% [23] and it can be evidenced as HBV infection is more prevalent among sex workers than the other population group.

Therefore, this study was proposed to determine the prevalence of Hepatitis B virus infection and its predisposing factors among FSWs in one of the hot spot cities of Ethiopia Hawassa. It could be important to emphasize the need for strengthening intervention strategies that address the risk and the marginalized group to stop the link or spread of HBV to the community through them and their sexual partners by designing vaccination schedules.

\section{Result}

\section{Demographic and socio-economic conditions}

Of the three hundred and eighty-four female sex workers who agreed to participate in the study, only three of them were excluded because of incomplete information from the questionnaire and also were not recruited for blood sample collection. For the remaining 381 FSWs, $45.7 \%$ of the participants were within the age group of 20-24 years with the mean (standard deviation [SD]) of age was $22.63 \pm 4.3$ years. The total median and range age of the participants were 22 and 16-40years. About $370(97.1 \%)$ were single and $11(2.9 \%)$ were previously 
married. Among 381 FSWs, 242(63.5\%) respondents were from urban. According to their educational level, 306(80.3\%) of the study participants were attended formal education. More than $35 \%$ of the study participants have a monthly income with the range of 1501 to 3000 Ethiopian Birr (Table 1).

\section{Sexual and behavioral characteristics of female commercial sex workers}

The overall prevalence of FSWs who were tested for HBV using ELISA (Enzyme linked Immunosorbent Assay) in the current study was 35(9.2\%). Among 381 FSWs workers, $249(65.4 \%)$ of them stayed for $2-5$ years in sexual

Table 1 Socio-demographic characteristics of female sex workers at integrated services on Health Development project confidential clinic Hawassa $2019(n=381)$

\begin{tabular}{|c|c|c|c|}
\hline Variables & & Frequency & Percent \\
\hline \multirow[t]{5}{*}{ Age in years } & $16-19$ & 91 & 23.9 \\
\hline & $20-24$ & 174 & 45.7 \\
\hline & $25-29$ & 90 & 23.6 \\
\hline & $30-34$ & 17 & 4.5 \\
\hline & $35-40$ & 9 & 2.4 \\
\hline \multirow[t]{4}{*}{ Marital status } & Married & 11 & 2.9 \\
\hline & Single & 289 & 75.9 \\
\hline & Widowed & 37 & 9.7 \\
\hline & Divorced & 44 & 11.5 \\
\hline \multirow[t]{5}{*}{ Educational Status } & No formal education & 75 & 19.7 \\
\hline & $1-4$ & 47 & 12.3 \\
\hline & $5-8$ & 204 & 53.5 \\
\hline & $9-12$ & 52 & 13.6 \\
\hline & Above 12th & 3 & .8 \\
\hline \multirow[t]{2}{*}{ Residence } & Rural & 139 & 36.5 \\
\hline & Urban & 242 & 63.5 \\
\hline \multirow[t]{4}{*}{ Religion } & Protestant & 201 & 52.8 \\
\hline & Orthodox & 164 & 43.0 \\
\hline & Muslim & 7 & 1.8 \\
\hline & Catholic & 9 & 2.4 \\
\hline \multirow[t]{3}{*}{ Living status } & Depend on family & 295 & 77.4 \\
\hline & Had another job & 75 & 19.7 \\
\hline & Other specify & 11 & 2.9 \\
\hline \multirow[t]{2}{*}{ Dependent people } & Yes & 187 & 49.1 \\
\hline & No & 194 & 50.9 \\
\hline \multirow[t]{3}{*}{ Dependent Size } & No dependents & 194 & 50.9 \\
\hline & $1-2$ & 141 & 37.0 \\
\hline & $2-4$ & 46 & 12.1 \\
\hline \multirow{4}{*}{$\begin{array}{l}\text { Average Monthly } \\
\text { Income in ETB }\end{array}$} & $501-1000$ & 104 & 27.3 \\
\hline & $1001-1500$ & 87 & 22.8 \\
\hline & $1501-3000$ & 136 & 35.7 \\
\hline & $3001-7000$ & 54 & 14.2 \\
\hline
\end{tabular}

ETB Ethiopian Birr work. 240(63\%) of them used condom consistently during sexual practice and $308(80.8 \%)$ had a habit of alcohol consumption. $100(26.2 \%)$ of them had a history of STI infection and 103(27\%) of FSWs had a steady partner. The majority of 287 (73.3\%) of the study subjects used vagina for sexual intercourse while 39(10.2\%) of them used anal and vaginal, $55(14.4 \%)$ used oral and vaginal sexual practice. About $243(63.8 \%)$ of the participants used injectable drugs and other stimulants to initiate their sexual desire (Table 2).

\section{Factors associated with $\mathrm{HBV}$ among female commercial sex workers}

Many different variables were assessed for the presence or absence of association HBV with female sex workers using both bivariate and multivariate logistic regression models. The bivariate analysis was computed independently, and we have used a cut-off $P$-value of 0.2 to recruit and analyze the variables in the multivariate model.

In multivariate logistic regression analysis, FSWs who didn't use condom commonly during sexual practice was significantly associated with acquiring of HBV $(\mathrm{AOR}=6.38$, CI 2.04-18.51), Condom breakage $(\mathrm{AOR}=2.10, \mathrm{CI} 1.95-4.65)$, use of stimulants, $(\mathrm{AOR}=3.25$, CI 1.59-18.63), history of STI, $(\mathrm{AOR}=2.15$, CI 1.02-6.93), history of genital ulcer, $(\mathrm{AOR}=4.64, \mathrm{CI}$ $1.31-11.35)$, number of clients used per day, $(\mathrm{AOR}=3.25$, CI 1.59-7.47), sex during menses ( $\mathrm{AOR}=5.85$, $\mathrm{CI}(1.29$ 21.44), sexual assault $(\mathrm{AOR}=2.93$, CI 1.23-9.01), sharp material sharing, $(\mathrm{AOR}=4.98, \mathrm{CI} 1.34-10.95)$ and History of abortion, $(\mathrm{AOR}=2.46$, CI 1.18, 12.19), were also statistically associated with $\mathrm{HBV}$ infection at $P$-value $<0.05$. Factors such as age, marital status, residence, alcohol consumption, and dependent size were not significantly associated with HBV infection among FSWs in the current study (Table 3).

\section{Discussion}

Ethiopia has been classified as an HBV endemic zones [22]. Although this classification gives a fair picture of the global HBV endemicity, it fails to take into account the variability of the disease within various population groups [22]. Also, most information on HBV prevalence in Ethiopia is available from blood donors and pregnant women [23]. In this study, the prevalence of HBsAg marker (indicating HBV infection) among female sex workers at integrated services on Health Development project confidential clinic Hawassa was 9.2\% (CI:95\%, $6.3-12.1 \%)$.

This prevalence is higher than in many other population groups studied in Ethiopia. This is critical owning to the fact that this group has a greater probability of transmitting and maintaining the virus in the community. 
Table 2 Sexual behavior of female sex workers at integrated services on Health Development project confidential clinic Hawassa 2019 $(n=381)$

\begin{tabular}{|c|c|c|c|}
\hline Variables & & Frequency & Percent \\
\hline \multirow[t]{4}{*}{ Place of sexual practice taken } & Hotel based & 172 & 45.1 \\
\hline & Street based & 160 & 42.0 \\
\hline & Home based & 48 & 12.6 \\
\hline & Any type & 1 & .3 \\
\hline \multirow[t]{2}{*}{ Condom utilization during sex } & Yes & 240 & 63.0 \\
\hline & No & 141 & 37.0 \\
\hline \multirow[t]{3}{*}{ Frequency of condom utilization } & Always & 185 & 48.6 \\
\hline & Sometimes & 43 & 11.3 \\
\hline & Rarely & 12 & 3.1 \\
\hline \multirow[t]{3}{*}{ Reason for not using condom } & To satisfy customers & 57 & 15.0 \\
\hline & To get more money & 74 & 19.4 \\
\hline & Negligence & 10 & 2.6 \\
\hline \multirow[t]{2}{*}{ Breakage of condom during sex } & Yes & 67 & 17.6 \\
\hline & No & 173 & 45.4 \\
\hline \multirow[t]{3}{*}{ Action taken during breakage of condom. } & Went to health facility & 10 & 2.6 \\
\hline & Nothing & 23 & 6.0 \\
\hline & Washing with water & 34 & 8.9 \\
\hline \multirow[t]{2}{*}{ Alcohol consumption } & Yes & 308 & 80.8 \\
\hline & No & 73 & 19.2 \\
\hline \multirow[t]{3}{*}{ Frequency of alcohol consumption } & Always & 74 & 19.4 \\
\hline & Sometimes having sex & 156 & 40.9 \\
\hline & Rarely & 78 & 20.5 \\
\hline \multirow[t]{2}{*}{ Utilization of injectable drugs/ stimulants before sex } & Yes & 243 & 63.8 \\
\hline & No & 138 & 36.2 \\
\hline \multirow[t]{4}{*}{ Type of stimulants/injectable drugs } & Khat only & 162 & 42.5 \\
\hline & Khat and cigarette & 15 & 3.9 \\
\hline & Khat and Shisha & 40 & 10.5 \\
\hline & Shisha only & 26 & 6.8 \\
\hline \multirow[t]{3}{*}{ Duration of prostitute commitment } & $<1$ years & 65 & 17.1 \\
\hline & $2-5$ years & 249 & 65.4 \\
\hline & $>6$ years & 67 & 17.6 \\
\hline \multirow[t]{3}{*}{ Sexual direction/position } & vaginal sex only & 287 & 75.3 \\
\hline & vaginal and anal & 39 & 10.2 \\
\hline & vaginal and oral & 55 & 14.4 \\
\hline \multirow[t]{2}{*}{ HBV vaccination } & Yes & 1 & .3 \\
\hline & No & 380 & 99.7 \\
\hline \multirow[t]{2}{*}{ History of STI infection } & Yes & 100 & 26.2 \\
\hline & No & 281 & 73.8 \\
\hline \multirow[t]{2}{*}{ Type of STI infection } & Syphilis & 18 & 4.7 \\
\hline & Gonorrhea & 82 & 21.5 \\
\hline \multirow[t]{2}{*}{ History of Genital ulcer } & Yes & 105 & 27.6 \\
\hline & No & 276 & 72.4 \\
\hline \multirow[t]{3}{*}{ Action on Genital ulcer } & Went to a health facility & 77 & 20.2 \\
\hline & treat with herbal treatment & 23 & 6.0 \\
\hline & nothing did & 5 & 1.3 \\
\hline \multirow[t]{2}{*}{ Presence of steady partner } & Yes & 103 & 27.0 \\
\hline & No & 278 & 73.0 \\
\hline
\end{tabular}


Table 2 (continued)

\begin{tabular}{llll}
\hline Variables & & Frequency & Percent \\
\hline Use of condom with steady partner & Yes & 55 & 48 \\
& No & 224 & 14.4 \\
Number of sexual partners per day & $<5$ & 157 & 11 \\
& $\geq 5$ & 370 & 48.8 \\
Sex during menses & Yes & 44 & 2.9 \\
& No & 337 & 97.1 \\
A habit of sexual abuse/ harassment & Yes & 10 & 11.5 \\
& No & 371 & 88.5 \\
History of blood transfusion? & Yes & 30 & 2.6 \\
Common use of Sharp material (tattooing) & No & 351 \\
History of Abortion & Yes & 36 & 7.9 \\
Place of abortion & No & 3.4 \\
HBV status & Yes & 345 \\
& No & 11 & 92.1 \\
\hline
\end{tabular}

Key: HBV Hepatitis B virus, ST/ Sexual transmitted infection

This finding was lower than the study reported from Gondar Ethiopia (11.9\%) [24], Nigeria (17.1\%) [ (25)], Cameroon (36\%) [26], Argentina (14.4\%) [27], Shanghai, China 12.3\% [28] in two different studies in Brazil 17.1\% [29] and 23.1\% [30].. The current finding was higher than the study conducted in Mekelle, Ethiopia (6\%) [31], Iran (1.2\%) [32], Rwanda (2.5\%) [33], Congo (7.3\%) [34], Italy (3.5\%) [35], Venezuela (3.8\%) [36], and Afghanistan (6.54\%) [37]. This difference might be due to the difference between diagnostic tools, sample size, differences in socio-demographic and socio-economic environments. Furthermore, the difference in the prevalence estimates is also likely to be influenced by stigma and discrimination and also study settings.

Compared to the prevalence general population $(6 \%)$ [31] it can be assumed that CSWs were more likely to have a high prevalence (9.2\%) of HBV in this study. Comparing this study results with the general population indicates that there less emphasis on this group of population.

The prevalence of HBV according to the age group of FSWs the highest prevalence 16(45.7\%) was accounted within the age group of 20-24years. But, the finding was not statistically significant $(p>0.05)$ which was inconsistent with the study conducted in Nigeria [25]. On the other hand, a similar finding to the current study was reported from Ethiopia, Dessie [13], and Burkina Faso [8]. The possible reasons may be the early onset of sexual intercourse represents an increased risk for sexually transmitted infections.

In this study, educational status, marital status, monthly income, vaccination, and alcohol consumption were not statically significant association with HBV similar to other studies conducted in three Afghan cities among female sex workers [38] in Mekelle among commercial sex workers [31] and in Tehran, Iran among female sex workers [39].

Sexual intercourse during menses is statically associated with acquiring HBV infection in sex workers $(\mathrm{AOR}=5.85$, 95\% CI: 1.29-21.44), FSW who have a history of abortion (AOR $=2.46,95 \% \mathrm{CI}: 1.18,12.19)$ and a genital ulcer $(\mathrm{AOR}=4.64,95 \% \mathrm{CI}: 1.31,11.35)$ were 24 and 46 times more risk full than those who have not a history of abortion and genital ulcer. Similar findings were reported from Mekelle, Ethiopia [31], Brazil [40], and Nigeria [25].

Sexual assault was 12 times more exposed for acquiring $\mathrm{HBV}(\mathrm{AOR}=2.93,95 \% \mathrm{CI}: 1.23,9.01)$ similar findings were reported from Iran [38] and Nigeria [25]. Number of sexual partners (AOR $=3.25,95 \% \mathrm{CI}: 1.59,7.47)$, duration on sex work $(\mathrm{AOR}=1.84,95 \% \mathrm{CI}: 1.33,2.14)$ and condom use $(\mathrm{AOR}=6.38,95 \% \mathrm{CI}: 2.04,18.51)$. In line with our finding was reported from Mexico [41]. The possible explanation may be multiple clients produce greater vulnerability to risks for low adherence to the use of condoms in all sexual relations. 
Table 3 Factors associated with HBV among females sex workers at Hawassa City, Southern Ethiopia, $2019(n=381)$

\begin{tabular}{|c|c|c|c|c|c|c|c|}
\hline Variables & & HBV (+) N (\%) & $\begin{array}{l}\text { HBV(-) } \\
\text { N (\%) }\end{array}$ & $\begin{array}{l}\text { COR } \\
(95 \% \mathrm{Cl})\end{array}$ & $P$-value & $\begin{array}{l}\text { AOR } \\
(95 \% \mathrm{Cl})\end{array}$ & $P$-value \\
\hline \multirow[t]{5}{*}{ Age in years } & $16-19$ & $5(14.3)$ & $86(24.6)$ & $2.15(0.22,20.73)$ & 0.060 & $0.47(0.05,4.49)$ & 0.330 \\
\hline & $20-24$ & $16(45.7)$ & $158(45.7)$ & $1.23(0.15,10.51)$ & & $0.81(0.09,6.90)$ & \\
\hline & $25-29$ & 10(28.6) & $80(23.6)$ & $1.0(0.11,8.85)$ & & $1.0(0.11,8.85)$ & \\
\hline & $30-34$ & $3(8.6)$ & $14(4.0)$ & $0.58(0.05,6.59)$ & & $1.71(0.15,19.34)$ & \\
\hline & $35-40$ & $1(2.9)$ & $8(2.3)$ & 1 & & 1 & \\
\hline \multirow[t]{4}{*}{ Marital status } & Married & $1(2.90)$ & 10(2.9) & 1 & 0.210 & 1 & 0.070 \\
\hline & Single & $26(74.3)$ & 263(76.0) & $1.01(0.13,8.22)$ & & $1.00(0.10,9.96)$ & \\
\hline & Widowed & $4(11.4)$ & $33(9.5)$ & $0.83(0.82,8.25)$ & & $1.01(0.34,3.05)$ & \\
\hline & Divorced & $4(11.4)$ & 40(11.6) & $1.0(0.10,9.96)$ & & $0.83(0.19,3.55)$ & \\
\hline \multirow[t]{4}{*}{ Educational Status } & No formal education & $7(20.0)$ & 68(19.7) & $1.19(0.38,3.76)$ & 0.090 & $0.84(0.27,2.66)$ & 0.103 \\
\hline & $1-4$ & $3(8.6)$ & $44(12.7)$ & $1.79(0.42,7.61)$ & & $0.56(0.13,2.36)$ & \\
\hline & $5-8$ & 19(54.3) & 185(53.5) & $1.19(0.45,3.15)$ & & $0.84(0.32,2.21)$ & \\
\hline & 9 and above & $6(17.1)$ & 49(14.2) & 1 & & 1 & \\
\hline \multirow[t]{2}{*}{ Residence } & Rural & $5(14.3)$ & 124(35.8) & 1 & 0.015 & 1 & 0.022 \\
\hline & Urban & $30(85.7)$ & $222(64.2)$ & $0.29(0.11,0.79)$ & & $0.74(0.37,1.51)$ & \\
\hline \multirow[t]{2}{*}{ Living status depend on } & Family & $31(88.6)$ & 188(54.3) & 1 & 0.001 & $0.98(0.43,2.25)$ & 0.140 \\
\hline & Not on family & $4(11.4)$ & $158(54.7)$ & $6.51(2.25,18.85)$ & & 1 & \\
\hline \multirow[t]{2}{*}{ Having dependent people } & Yes & $28(80.0)$ & 159(46.0) & 1 & 0.001 & 1 & 0.120 \\
\hline & No & $7(20.0)$ & 187(54.0) & $4.70(2.00,11.06)$ & & $1.28(0.43,3.84)^{*}$ & \\
\hline \multirow[t]{4}{*}{ Monthly Income } & $501-1000$ & $8(22.9)$ & $90(26.0)$ & $0.99(0.20,2.39)$ & 0.230 & & 0.250 \\
\hline & $1001-1500$ & 15(42.9) & $62(17.9)$ & $0.69(0.08,0.81)$ & & & \\
\hline & $1501-3000$ & $8(22.9)$ & 129(37.3) & $0.25(0.29,3.42)$ & & & \\
\hline & $3001-7000$ & $4(11.4)$ & $65(18.8)$ & 1 & & & \\
\hline \multirow[t]{3}{*}{ Dependent Size } & No dependents & $7(20.0)$ & 187(54.0) & 1 & 0.001 & $0.94(0.34,2.61)$ & 0.080 \\
\hline & $1-2$ & $23(65.7)$ & 118(34.1) & $0.19(0.80,0.46)$ & & $0.55(0.17,1.84)$ & \\
\hline & $2-4$ & $5(14.3)$ & $41(11.8)$ & $0.31(0.09,1.02)$ & & 1 & \\
\hline \multirow[t]{2}{*}{ Condom use } & Yes & 10(28.6) & $230(66.5)$ & 1 & 0.001 & 1 & $0.010^{*}$ \\
\hline & No & $25(71.4)$ & $116(33.5)$ & $4.96(2.30,10.67)$ & & $6.38(2.04,18.51)$ & \\
\hline \multirow[t]{2}{*}{ Condom Breakage during sex } & Yes & $6(60.0)$ & $61(26.5)$ & $4.16(1.13,15.23)$ & 0.030 & $2.10(1.95,4.62)$ & $0.030^{*}$ \\
\hline & No & $4(40.0)$ & 169(73.5) & 1 & & 1 & \\
\hline \multirow[t]{2}{*}{ Alcohol consumption } & Yes & $21(60.0)$ & 287(82.9) & $3.24(1.56,6.74)$ & 0.001 & $1.21(0.45,3.26)$ & 0.140 \\
\hline & No & $14(40.0)$ & $59(17.1)$ & 1 & & 1 & \\
\hline \multirow[t]{2}{*}{ Use of stimulant } & Yes & 29(82.9) & 214(61.8) & $2.98(1.21,7.37)$ & 0.013 & $3.25(1.59,18.63)$ & $0.018^{*}$ \\
\hline & No & $6(17.1)$ & 132(38.2) & 1 & & 1 & \\
\hline \multirow[t]{3}{*}{ Duration of prostitution service } & $<1$ & $3(8.6)$ & $62(17.9)$ & $4.74(1.30,17.34)$ & 0.001 & 1 & $0.020^{*}$ \\
\hline & $2-5$ & $18(51.4)$ & $223(64.5)$ & $2.84(1.34,6.04)$ & & $2.03(0.49,8.50)$ & \\
\hline & $>6$ & $14(40.0)$ & $61(17.6)$ & 1 & & $1.84(1.33,2.14)$ & \\
\hline \multirow[t]{3}{*}{ Type of sex usually used } & Vaginal only & $24(68.6)$ & 263(76.0) & 1 & 0.080 & $1.20(0.34,4.26)$ & 0.980 \\
\hline & Vaginal and anal & $5(14.3)$ & $34(9.8)$ & $0.62(0.22,1.73)$ & & $0.75(0.29,1.92)$ & \\
\hline & Vaginal and oral & $6(17.1)$ & $49(14.2)$ & $0.75(0.29,1.92)$ & & 1 & \\
\hline \multirow[t]{2}{*}{ Vaccinated } & Yes & $1(2.9)$ & $1(0.3)$ & 1 & 0.180 & 1 & 0.230 \\
\hline & No & $34(97.1)$ & $345(99.7)$ & $10.15(0.62,165.88)$ & & $0.99(0.06,1.61)$ & \\
\hline \multirow[t]{2}{*}{ History of STI } & Yes & $20(57.1)$ & $80(23.1)$ & $4.43(2.17,9.06)$ & 0.001 & $2.15(1.02,6.93)^{*}$ & $0.011^{*}$ \\
\hline & No & $15(42.9)$ & $266(76.9)$ & 1 & & 1 & \\
\hline \multirow[t]{2}{*}{ History of Genital ulcer } & Yes & 18(51.4) & $87(25.1)$ & $3.15(1.56,6.39)$ & 0.001 & $4.64(1.31,11.35)$ & $0.004^{*}$ \\
\hline & No & 17(48.6) & 259(74.9) & 1 & & 1 & \\
\hline \multirow[t]{2}{*}{ Number of clients used per day } & $<5$ & $9(25.7)$ & 202(58.4) & 1 & 0.001 & 1 & $0.018^{*}$ \\
\hline & $\geq 5$ & $26(74.3)$ & 144(41.6) & $4.05(1.84,8.91)$ & & $3.25(1.59,7.47)$ & \\
\hline
\end{tabular}


Table 3 (continued)

\begin{tabular}{|c|c|c|c|c|c|c|c|}
\hline Variables & & HBV (+) N (\%) & $\begin{array}{l}\text { HBV(-) } \\
\mathrm{N}(\%)\end{array}$ & $\begin{array}{l}\text { COR } \\
(95 \% \mathrm{Cl})\end{array}$ & $P$-value & $\begin{array}{l}\text { AOR } \\
(95 \% \mathrm{Cl})\end{array}$ & $P$-value \\
\hline \multirow[t]{2}{*}{ Sexes during menses } & Yes & $4(11.4)$ & $7(2.0)$ & $6.25(1.7,22.53)$ & 0.001 & $5.85(1.29,21.44)$ & $0.002^{*}$ \\
\hline & No & $31(88.6)$ & $339(98.0)$ & 1 & & 1 & \\
\hline \multirow[t]{2}{*}{ Sexual Assault } & Yes & $9(25.7)$ & $35(10.1)$ & $3.08(1.34,7.09)$ & 0.001 & $2.93(1.23,9.01)$ & $0.007^{*}$ \\
\hline & No & $26(74.3)$ & $311(89.9)$ & 1 & & 1 & \\
\hline \multirow[t]{2}{*}{ Blood received } & Yes & $2(5.7)$ & $8(2.3)$ & 1 & 0.120 & 1 & 0.080 \\
\hline & No & 33(94.3) & $338(97.7)$ & $2.56(0.52,12.56)$ & & $0.39(0.08,1.92)$ & \\
\hline \multirow[t]{2}{*}{ Use of sharp material } & Yes & $8(22.9)$ & $22(6.4)$ & $4.36(1.78,10.73)$ & 0.001 & $4.98(1.34,10.95)$ & $0.008^{*}$ \\
\hline & No & 27(77.1) & 324(93.6) & 1 & & 1 & \\
\hline \multirow[t]{2}{*}{ History of Abortion } & Yes & $9(25.7)$ & $30(8.7)$ & $3.65(1.67,8.49)$ & 0.001 & $2.46(1.18,12.19)$ & $0.001^{*}$ \\
\hline & No & $26(74.3)$ & $316(91.3)$ & 1 & & 1 & \\
\hline
\end{tabular}

Key: AOR adjusted odds ratio, Cl confidence interval, COR crude odds ratio, OR odds ratio, STI Sexually Transmitted infections

* $=$ Significant at $p<0.005$

Limitations of the current study were due to significant difficulties encountered in attempting to recruit the needed sample size from the FSWs population. Female sex workers in Ethiopia are mainly street-based which makes it quite tough and threatening to reach them. A follow-up study with a larger sample size with longitudinal study in the different study areas is worthwhile to add to the literature.

\section{Conclusion}

Despite the limitations in difficulties encountered in attempting to recruit the study participants, the prevalence of HBV infection among FSWs was relatively high compared to the general population in the current study. Furthermore, different factors like sociodemographic, behavioral, clinical, and previous history-related information have been also assessed for the presence of association with HBV infection. Condom use, history of genital ulcer, sexes during menses, sexual assault, history of abortion, Number of sexual partners, duration of sex work, and sharing of sharp material were highly associated with HBV infection among female sex workers. Meanwhile, they are at a higher risk of acquiring HBV infection, as indicated above due to high-risk behaviors of sex practice and lack of successful HBV immunization evidence. Preparedness should be initiated to prevent the potential risk of HBV infection. Since they can be a source of infection for the community, first, a mass screening activity or a longitudinal survey study on FSWs should be done. Then, a preventive approach and appropriate treatment scheme for HBV should be developed.

Finally, the government, any other nongovernmental organizations, civic society, and religious institutions should work together to alleviate the problem by counseling and recruiting them on other productive job sectors that are found in the country.

\section{Methods \\ Study area}

This study was conducted in Sidama regional state of Hawassa City in one of the nongovernmental institutions founded to support marginalized populations to give integrated services on Health Development (ISHDO) project confidential clinic. Hawassa city is the central town of the regional state located $270 \mathrm{~km}$ from Addis Ababa at the shores of Lake Hawassa in the Great Rift Valley area of southern Ethiopia. It is known by diverse cultural constituents, socio-economic benefit, and good tourist destination and recreational city with a total population of 302, 000 according to the Worldometer report of 2021 [21].

\section{Study design, period, and population}

A cross-sectional study design was employed among adolescent and young adult female sex workers from July 1-November 31st, 2019, who are living in Hawassa city working as a commercial sex worker for at least 3 months and registered in the nongovernmental institutions founded to support marginalized populations to give at integrated services on Health Development (ISHDO) project confidential clinic were selected and included in the study.

A single population proportion formula was used to estimate the sample size, following the assumption to consider: $95 \%$ confidence interval $(Z \alpha / 2=1: 96), 50 \%$ proportion was taken due to limited data about HBV among FSWs in the area and nearby localities, and 5\% margin of error.

$$
n=(Z a / 2)^{2} P(1-P) / d^{2}=384
$$

A total of 384 female sex workers were included from eight sub-cities and from all kebeles who were 
pre-registered in the registration book. They were selected using a simple random sampling method by using assigned ex-sex workers, namely: "Demand creator" and preregistered FSWs to bring their counterparts by moving from home to home and brought to this special clinic were participated.

Female sex workers registered in the nongovernmental institutions founded to support marginalized populations to give an integrated service on Health Development (ISHDO) project confidential clinic were included in the study. We have considered and defined women as FSWs when they are living and commercializing sex for the last 3 months in Hawassa City. Female sex workers with age greater than or equal to 18 years old and who are willing to participate in this study were included, but those FSWs with apparent mental or physical illness that limit them from an interview and those who are not available during the study period were excluded.

\section{Specimen collection}

A simple random sampling technique was used to select 384 study participants during the study period. Before the actual data collection, we have studied the average number of FSWs registered in the clinic. About 626 FSWs were registered in the clinic at start of data collection including the newly registered participants with daily visit of 18 FSWs. Every 2nd participant was going to be included in the study each day.

\section{Data collection methods}

After obtaining an informed and written consent, a standardized questionnaire was used to collect the sociodemographic, behavioral, and other predisposing variables that are associated with the dependent variable. Five milliliters of venous blood was drawn under aseptic conditions by trained data collectors. The sample was labeled and processed by centrifugation at $3500 \mathrm{rpm}$ for $5 \mathrm{~min}$ to obtained serum and stored at $-20^{\circ} \mathrm{c}$ in the refrigerator until it was tested. HBsAg was detected from serum samples by using $\mathrm{AiD}^{\mathrm{TM}}$ antibody sandwich HBsAg ELISA method (WANTAI HBV diagnostics AiD ${ }^{\mathrm{TM}}$ HBsAg ELISA). The test was conducted following the manufacturer's instructions and the Microplates read at a wavelength of $450 \mathrm{~nm}$ using the Enzyme-linked immune assay (ELISA) reader. The presence or absence of HBsAg was determined by relating the absorbance of the unknown sample to the cut-off value.

\section{Statistical analysis}

Data were cleaned and checked and entered into SPSS version 21 for analysis. The data were analyzed using descriptive summary using frequencies, appropriate summary tables, and cross tabs, and relevant information was summarized to present results. Bivariate logistic regression analysis was performed to identify the factors associated with HBV infection. Variables having a $P$-value of $<0.2$ in bivariate analysis were eligible for multivariate logistic regression analysis to control potential confounding factors. A $p$-value of less than 0.05 is considered as statistical significance.

\section{Abbreviations \\ ISHDO: Integrated services on Health development; HBV: Hepatitis B virus; HBsAg: Hepatitis B surface antigen; FSW: Female sex workers; STIs: Sexually transmitted infections; AOR: Adjusted odds ratio; COR: Crude odds ratio; WHO: World Health Organization.}

\section{Acknowledgments}

We are grateful to Hawassa University for its technical and financial support. We would also like to thank the Integrated Service on Health and Development Organization (ISHDO) for their permission and guidance to undertake this research in their organization. Finally, we also thank all participants of the study.

\section{Authors' contributions}

DD: Conceived and designed the study, analyzed the data, involved in manuscript preparation, Involved in protocol development and manuscript write-up. GHM, Conceived and designed the study, supervised the study, involved in analysis and manuscript preparation. DA: Designed, supervised data collection, data analysis, writes up. All authors read and approved the final manuscript

\section{Funding}

This study was supported by Hawassa University, College of Medicine and Health Sciences. The support included payment for data collectors and the purchase of materials and supplies required for the study. The support did not include designing the study, analysis, interpretation of data, manuscript preparation, and publications.

\section{Availability of data and materials}

The datasets used and/or analyzed during the current study are available from the corresponding author on reasonable request.

\section{Declarations}

\section{Ethics approval and consent to participate}

Ethical approval was obtained from Hawassa University Institutional Review Board (IRB) under the reference number of Ref.No IRB/026/2010 signed by the chairperson of Dr. Ayalew Astateke on 21/12/2018 and the study was conducted in accordance with Helsinki declaration and according to the ethical review guideline of Ethiopia Consent was sought instead of assent for individuals who has ethical dilemma. Finally a permission letter was obtained from the Southern Nation, Nationality, and People Regional Health Bureau to the respective health institutions. Written informed consent was obtained from each participant before data collection. After informing each respondent about the aim and purpose of the study, participants were asked for their voluntary participation. Those respondents were assured that they could withdraw from the study at any time if they felt unhappy. They were also informed that all data obtained from them would be kept confidential by using codes instead of any personal identifiers.

Consent for publication

Not applicable.

Competing interests

The authors declare that they have no competing interests. 


\begin{abstract}
Author details
'School of Medical Laboratory Science, College of Medicine and Health Science, Hawassa University, Hawassa, Ethiopia. ${ }^{2}$ Department of Laboratory Hawassa University Comprehensive Specialized Hospital, Hawassa, Ethiopia.
\end{abstract}

Received: 30 June 2021 Accepted: 13 January 2022

Published online: 31 January 2022

\section{References}

1. Hwang EW, Cheung R. Global epidemiology of hepatitis B virus (HBV) infection. North Am J Med Sci. 2011;4(1)

2. World Health Organization. World health statistics 2013: a wealth of information on global public health. World Health Organization; 2013.

3. Akani C, Ojule A, Opurum H, Ejilemele A. Sero-prevalence of hepatitis B surface antigen (HBsAg) in pregnant women in Port Harcourt, Nigeria. Niger Postgrad Med J. 2005;12(4):266-70.

4. Spearman C, Afihene M, Ally R, Apica B, Awuku Y, Cunha L. Hepatitis B in sub-Saharan Africa: strategies to achieve the 2030 elimination targets. Lancet Gastroenterol Hepatol. 2017;2(12):900-9.

5. Scorgie F, Chersich MF, Ntaganira I, Gerbase A, Lule F, Lo Y-R. Socio-demographic characteristics and behavioral risk factors of female sex workers in sub-Saharan Africa: a systematic review. AIDS Behav. 2012;16(4):920-33.

6. Niama FR, Bongolo NCL, Mayengue PI, Mboussou FF, Bayonne ESK, Nzingoula FMK, et al. A study on HIV, syphilis, and hepatitis B and C virus infections among female sex workers in the republic of Congo. Arch Public Health. 2017:75(1):1-8.

7. Forbi JC, Onyemauwa N, Gyar S, Oyeleye A, Entonu P, Agwale S. High prevalence of hepatitis B virus among female sex workers in Nigeria. Rev Inst Med Trop Sao Paulo. 2008;50(4):219-21.

8. Ouedraogo HG, Kouanda S, Goodman S, Lanou HB, Ky-Zerbo O, Samadoulougou BC, et al. Hepatitis B, C and Delta viruses'infections and correlate factors among female sex workers in Burkina Faso, West-Africa. Open Virol J. 2019;13(1).

9. Scheibe A, Young K, Versfeld A, Spearman CW, Sonderup MW, PrabdialSing N, et al. Hepatitis B, hepatitis C, and HIV prevalence and related sexual and substance use risk practices among key populations who access HIV prevention, treatment, and related services in South Africa: findings from a seven-city cross-sectional survey (2017). BMC Infect Dis. 2020;20(1):1-15.

10. Mutagoma M, Nyirazinyoye L, Sebuhoro D, Riedel DJ, Ntaganira J. Syphilis and HIV prevalence and associated factors to their co-infection, hepatitis B and hepatitis C viruses prevalence among female sex workers in Rwanda. BMC Infect Dis. 2017;17(1):1-9.

11. Moges F, Kebede Y, Kassu A, Mulu A, Tirunch M, Degu G, et al. Seroprevalence of HIV, hepatitis B infections and syphilis among street dwellers in Gondar city, Northwest Ethiopia. Ethiop J Health Dev. 2006;20(3).

12. Bugssa G, Dessalegn B, Dimtsu B, Berhane Y. Prevalence and factors associated with HIV and hepatitis B virus infections among female commercial sex workers in Mekelle, Ethiopia: cross-sectional study. Int J Pharm Sci Res. 2015;6(1):135.

13. Metaferia Y, Ali A, Eshetu S, Gebretsadik D. Seroprevalence and associated factors of human immunodeficiency virus, treponema pallidum, hepatitis B virus, and hepatitis C virus among female sex workers in Dessie City, Northeast Ethiopia. Biomed Res Int. 2021;2021.

14. Afonso Dinis Costa Passos JFCF, de Lourdes Candolo Martinelli A, et al. Hepatitis B among female sex workers in Ribeirão Preto - São Paulo, Brazil. REv, Bras Epidemiol. 2007;10:517-24.

15. Su S, Chow EP, Muessig KE, Yuan L, Tucker JD, Zhang X, et al. Sustained high prevalence of viral hepatitis and sexually transmissible infections among female sex workers in China: a systematic review and meta-analysis. BMC Infect Dis. 2015;16(1):1-10.

16. Hongjaiseea S, Khamduang W, Sripana P, Choyrumb S, Thepbunditb V, Ngo-Giang-Huong N, et al. Prevalence and factors associated with hepatitis $B$ and $D$ virus infections among migrant sex workers in Chiangmai, Thailand: A cross-sectional study. Int J Infect Dis. 2020;2019(100):247-54.

17. Risbud A, Mehendale S, Basu S, Kulkarni S, Walimbe A, Arankalle V, et al. Prevalence and incidence of hepatitis B virus infection in STD clinic attendees in Pune, India. Sex Transm Infect. 2002;78:169-73.

18. Remple VP, Patrick DM, Johnston C, Tyndall MW, Jolly AM. Clients of indoor commercial sex workers: heterogeneity in patronage patterns and implications for HIV and STI propagation through sexual networks. Sex Transm Dis. 2007;34(10):754-60.

19. Lawan UM, Abubakar S, Ahmed A. Risk perceptions, prevention and treatment-seeking for sexually transmitted infections and HIV/AIDS among female sex workers in Kano, Nigeria. Afr J Reprod Health. 2012;16(1):61-7.

20. Csa I. Central statistical agency (CSA)[Ethiopia] and ICF. Ethiopia demographic and health survey, Addis Ababa, Ethiopia and Calverton, Maryland, USA; 2016.

21. Review WP. Ethiopia Population 2021. woldometer report. 2021.

22. WHO. The prevention and control of viral hepatitis: in WHO member states. Geneva. Global policy report on. 2013.

23. Tegegne DDK, Tegbaru B, et al. Seroprevalence and transmission of hepatitis $B$ virus among delivering women and their newborn in selected health facilities, Addis Ababa, Ethiopia: a cross-sectional study. BMC research. Notes. 2014;7(239):2-7

24. Moges F, Kebede Y, Kassu A, Mulu A, Tirunch M, Degu G, Adugna S, Alem A, Wale F. Seroprevalence of HIV, hepatitis B infections and syphilis among street dwellers in Gondar city, Northwest Ethiopia. Ethiop J Health Dev. 2006;20(3).

25. Forbi JCON, Gyar SD, et al. High prevalence of hepatitis B virus among female sex workers in Nigeria. Rev Inst Med trop S Paulo. 2008;50:219-21.

26. (PEPFAR). PsEPfAR. Cameroon Operational plan report 2011:

27. María A, Pando CB, Bibini M, et al. Prevalence of HIV and other sexually transmitted infections among female commercial sex workers in Argentina. Am J Trop Med Hyg. 2006;74:233-8.

28. Zhang TYY, Yu F, et al. Kaposi's sarcoma-associated herpesvirus infection among female sex workers and general population women in Shanghai, China: a cross-sectional study. BMC Infect Dis. 2014;14:58.

29. Matos MAFD, Carneiro MAS, et al. Viral hepatitis in female sex workers using the Respondent-Driven Sampling. Rev Saude Publica. 2017;51.

30. Fabiana Schuelter-Trevisol GC, da Silva ACB, et al. HIV, hepatitis B and C, and syphilis prevalence and coinfection among sex workers in southern Brazil. Rev Sociedade Brasil Trop. 2013;46:493-7.

31. Gessessew Bugussa BD, Dimitu B, et al. Prevalence and factors associated with HIV and hepatitis B virus infection among female commercial sex workers in Mekelle, Ethiopia: cross-sectional study. IJPSR. 2015;6:135-46.

32. Moayedi-Nia SBJZ, Esmaeeli Djavid G, et al. HIV, HCV, HBV, HSV, And syphilis prevalence among female sex workers in Tehran, Iran, by using respondentdriven sampling. AIDS Care. 2016;28:487-90.

33. Mutagoma MNL, Sebuhoro D, et al. Syphilis and HIV prevalence and associated factors to their co-infection, hepatitis B and hepatitis $C$ viruses prevalence among female sex workers in Rwanda. BMC Infect Dis. 2017:17:525.

34. Fabien Roch Niama NCLB, Mayengue PI, et al. A study on HIV, syphilis, and hepatitis $B$ and $C$ virus infections among female sex workers in the republic of Congo BMC. Arch Public Health. 2017;75.

35. Monica Zermiani CM, Raimondo C, et al. Prevalence of sexually transmitted diseases and hepatitis $C$ in a survey of female sex Workers in the North-East of Italy. Open AIDS J. 2012;6:60-4.

36. Camejo MIMG, Diaz M. Prevalence of hepatitis B, hepatitis $C$, and syphilis in female sex workers in Venezuela. Rev Saúde Publica. 2003;37.

37. Catherine S, Todd AN, Mohammad R, Stanekzai, et al. HIV, hepatitis B, and hepatitis $C$ prevalence and associated risk behaviors among female sex workers in three Afghan Cities. NIH, AIDS. 2010;24:S69-75.

38. Todd CS, Nasir A, Stanekzai MR, Bautista CT, Botros BA, Scott PT, et al. HIV hepatitis $B$, and hepatitis $C$ prevalence and associated risk behaviors among female sex workers in three Afghan cities. AIDS (London, England). 2010:24(0 2):\$69.

39. Nasirian M, Kianersi S, Hoseini SG, Kassaian N, Yaran M, Shoaei P, et al. Prevalence of sexually transmitted infections and their risk factors among female sex workers in Isfahan, Iran: a cross-sectional study. J Int Assoc Providers of AIDS Care (JIAPAC). 2017;16(6):608-14.

40. Matos MAFD, Carneiro MAS, et al. Viral hepatitis in female sex workers using the respondent-driven sampling. Rev Saude Publica. 2017;51.

41. Juárez-Figueroa LU-SF, Conde-Glez C, et al. Low prevalence of hepatitis $B$ markers among Mexican female sex workers. Sex Transm. 1998;74:448-50.

\section{Publisher's Note}

Springer Nature remains neutral with regard to jurisdictional claims in published maps and institutional affiliations. 